\title{
The drum and its significance for the interpretation of the Old Testament from an African perspective: Part two
}

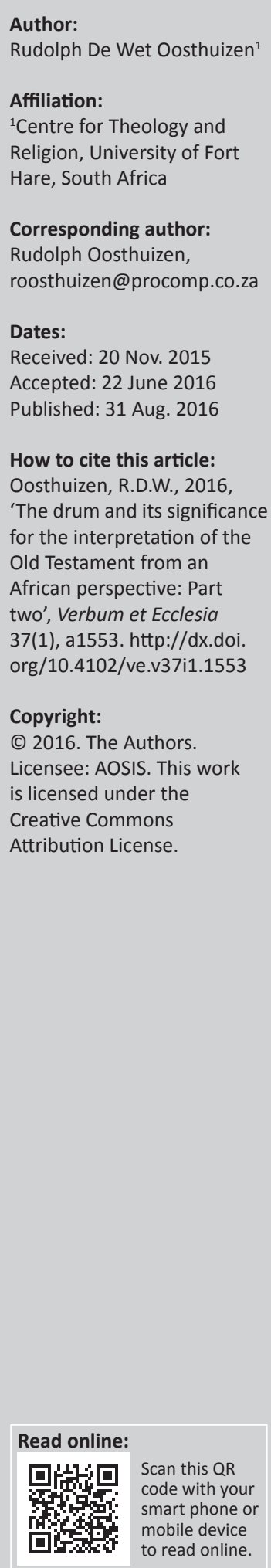

Allowing the (South) African context to inform the construction and enhancement of the comparative paradigm as a reading strategy for the interpretation of the Old Testament enables one to identify and appreciate aspects of significance for the contemporary reader, relating to the interpretation of the text. Bearing in mind the importance of music and its function regarding religious expression, various aspects pertaining to the function and significance of music are being explored in order to enrich the interpretation of Psalm 150, with specific reference to music and musical instruments. (Whilst the focus in Part one [Oosthuizen 2016] is more on some hermeneutical aspects as pertaining to a specific reading strategy, Part two explores the significance of music for the interpretation of the Old Testament from an African perspective with specific reference to the drum and its usage in Psalm 150). Music enables one to comprehend and articulate a very particular aspect of religious experience, and it is of the utmost importance that this be acknowledged and taken into account in the current debate regarding appropriate strategies for the interpretation of religious texts in an African context. Three aspects serve to illustrate how the comparative approach can be augmented by drawing attention to aspects of particular interest for an African reading of the Old Testament: 'music as space to encounter the divine', the infectious nature of music, and 'drumming' as a point of contact between the Old Testament and Africa.

Intradisciplinary and/or interdisciplinary implications: In our encounters with the biblical text, the (South-) African context can inform a comparative reading of the Old Testament. In so doing, the 'comparative paradigm' is augmented by allowing insights from various disciplines to inform the reader and to apprise a reading strategy that allows for the encounter with the text to be understood not merely in terms of a historical-descriptive or linguistic exercise only, but provides an opportunity to explore various perspectives pertaining to the appreciation and interpretation of the text (Psalm 150).

Christianity in (South) Africa, in order to take up its legitimate place in the history of the Church, need to establish its own identity with due recognition of its uniqueness, specifically in terms of its own cultural heritage. (Martey 1993:55)

Music ... will help dissolve your perplexities and purify your character and sensibilities, and in time of care and sorrow, will keep a fountain of joy alive in you. (Bonhoeffer 2013:n.p.)

\section{Introduction}

One finger cannot play the drum alone ... ${ }^{1}$

In a prelude (Oosthuizen 2016) regarding the significance of the drum for the interpretation of the Old Testament from an African perspective, some broad parameters were drawn whereby exegesis came to be defined as more than a mere historically descriptive enterprise, acknowledging the fact that in our encounters with the biblical text or Old Testament, method is not to be seen as an end in itself (Le Roux 2002:1; Ukpong 1999). ${ }^{2}$ In appreciation and acknowledgement of an 'African orientation' (Ukpong 1999) that characterises a particular outlet of Old Testament scholarship, and in order to augment the comparative approach (West 2005), an attempt is being made to illustrate how the African context can inform a comparative reading of the Old Testament, with specific

1.Well known African expression pointing to the importance of communal interests, solidarity and identity formation, as implied in Oosthuizen (2016:3,5). In this regard see also Healy and Sybertz (1996).

2.'In die hermeneutiek gaan dit nie primêr om 'n metode nie. Dit gaan om die lewe. Of anders gestel: ons lewens. Ons is van nature wesens wat interpreteer: die lewe, tekste, die verlede en nog baie ander dinge meer. En in hierdie proses van interpretasie kan geen metode die finale betekenis vir ons ontsluit. nie ' $n$ Metode is belangrik, maar dit het ook sy perke' (Le Roux 2002). Rough translation hermeneutics is not just about method but about life in as far as interpretation of life, texts, the past et cetera is part of our existence. Despite its importance, it cannot elucidate meaning as such and method has certain perks and also constraints. 
reference to the drum and its significance for the interpretation of Psalm 150. In order to do this, the significance of musical instruments and/or references to music and musical instruments, such as the drum, are herewith being explored to apprise a reading strategy that allows for the encounter with the text to be understood not merely in terms of a linguistic exercise, that is, analysis of the text not only in terms of historically descriptive categories, ${ }^{3}$ but also in terms of the contemporary reader's appreciation of the 'text' ${ }^{4}$ and the role that the 'text' can play in the construction of meaning and religious experience. 'Text' is to be appreciated in terms of the linguistic characteristics thereof, but not to be restricted to syntax and/or defined only with reference to historical context, as implied by the concept 'intertextuality' (Tull 2000:59).

Tull (2000:60) acknowledged the fact that understanding of a 'text' can also be defined in categories 'beyond the written word' and to 'encompass all signs (or "signifiers") which call for interpretation'. In this regard, the question by Kwami (1989:36) is noteworthy - 'To what extent can African drumming be described (as) a form of literature, poetry or language?' In this case, the interpretation of Psalm 150 is to be explored in the sense of performance or enactment of a particular kind, that is, a reading or presentation of a specific text accompanied by musical instruments and in the context of a specific religious or cultic activity (not necessarily restricted to Temple worship only), whilst appreciating the significance of music and musical terminology in interpreting the text. In this regard Stern (2013:191ff.) acknowledges the significance of 'text-supported performance' within the context of 'ritual recitation' as 'vehicle for the communication of scriptural content'.

In looking at Psalm 150, through the African perspective, the significance of the drum as another vehicle of communication within the context of religious experience speaks for itself, bearing in mind that, in Africa, the drum can be regarded as the most popular and widely used musical instrument (Gathogo 2008:282; Lury 1956:36; Parrinder 1956:38) and 'is inseparably united with African song' (Weman 1960:199). Furthermore, listening to the drums provides for an opportunity to be drawn into the 'magic circle of African music' (Weman 1960:18), and also to participate in various activities involving drums (City College of New York - CCNY Theatre Ed. Dept. 2016), where the voice of God can be heard (Hester 2010):

Traditional African societies acknowledged that the drum had a spirit and character that was clearly observable. The gift of the voices of the Great Ancestors had been hidden inside the wood of trees so they could be accessed whenever men and women needed them. (p. 9)

\section{As indicated by Weman (1960):}

3.Van Zyl (1995:425-438) points to the various aspects that characterise the western approach and its preference for literary and historical interests.

4.'Text' is to be understood as an encounter with the text that moves beyond a linguistic exercise and incorporates aspects of the perception and experience of such an encounter, past and present.
The drum is the African's own instrument, and one which he needs in order to be able to experience music to the full. For him it is more than just a matter of accompaniment; he is able with the drum to make his music into a flowing rhythmic polyphony [and in this case, allowing one to explore new dimensions regarding the analysis of the text \{Psalm 150\} in an African context/setting]. (p. 199)

In so doing the significance of the talking drums (Oerhle 2013:135ff. $)^{5}$ is taken into consideration and allows one to present aspects pertaining to the interpretation of Psalm 150, which are not always recognised:

Psalm 150:1 Praise ye
the LORD. Praise God
in his sanctuary:
praise him in the
firmament of his
power.
${ }^{2}$ Praise him for his
mighty acts: praise
him according to his
excellent greatness.
${ }^{3}$ Praise him with the
sound of the trumpet:
praise him with the
psaltery and harp.
${ }^{4}$ Praise him with the
timbrel and dance:
praise him with
stringed instruments
and organs.
5 Praise him upon the
loud cymbals: praise
him upon the high
sounding cymbals.
6 Let every thing that
hath breath praise the
LORD.
Praise ye the LORD.
(KJV)

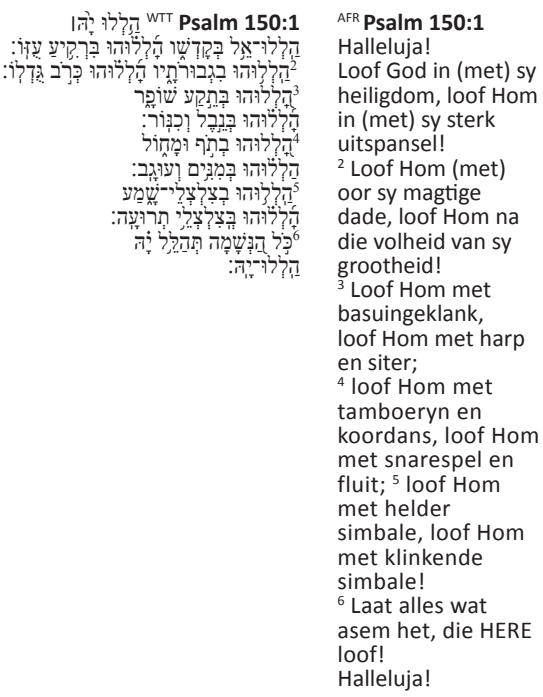

The choice of Psalm 150 is based on the comprehensive catalogue of musical instruments ${ }^{7}$ referred to (Human 2011:5): 'Verses 3-5 catalogue the largest list of musical instruments in the whole of the Psalter'.

Weiser (1962:841) rightly emphasised the impact and significance of this Psalm in its current form in musical terms as 'a mighty final chord'.

\section{'Drums of Praise's}

Psalm 150 is, generally speaking, regarded as a 'song of praise' or simply a 'call to sing the praise of God' (Weiser 1962:841).Thematically, the inner structure of Psalm 150:3-5 emphasises how God is to be praised (Human 2011:4). Structures that issue emphasis include the use of word pairs, repetition (Anderson 1972:955) and sound imitation whilst making use (?ִ̣ - particle or preposition - with, used nine

5.The concept 'Talking Drums' is not new (see for example Carrington, J.F., Talking Drums of Africa, London 1959, in Weman 1960: 187) and serves to emphasize the fact that the significance of the drum moves beyond linguistic descriptions but also allows one to appreciate the connection between music and words.

6.Biblical text: (KJV) - King James (1611/1769) with Codes, (AFR) - Afrikaans Bible (1953), (WTT) - Leningrad Hebrew Old Testament. Ref BibleWorks 9 (BibleWorks ${ }^{\text {TM }}$ Copyright $^{\circledR} 1992-2013$ BibleWorks, LLC. (BibleWorks was programmed by Michael S. Bushell, Michael D. Tan and Glenn L. Weaver) BibleWorks- Norfolk, VA.

7.See also Kolyada (2009) for a comprehensive overview of musical instruments and terminology in the Bible.

8.See Lowell, Piper (1995), who elaborates on the use of African tribal heritage to spawn new forms of worship in the sense of developing new spiritual identities, amongst others, by appreciating the role of music, and more specifically the drum and its religious or theological significance. 
times) of the different accompanying musical instruments. ${ }^{9}$ The multiple usage of the preposition (?ִ / 'be') begs the question of a possible onomatopoetic usage, to resemble the rhythmic sound of a timbrel/drum and to function as a mnemonic device (Kwami 1989:37). The reference to various musical instruments (Ps 150: 3, 4, 5) and the utilisation of various durational measures (e.g. Ps 150:1- הַלְלוּ ילה ) in the poem emphasises the link between language and music. ${ }^{10}$

Although there is no specific title for the psalm, except the call to praise the Lord (הלכלוּ יזה), the usage of this specific phrase or form of the verb with the specific reference to multiple musical instruments clearly points to the use and function of the psalm within a context where music played an integral part in the reception and appreciation of the psalm. As such, the interpretation and appreciation of the psalm is not to be defined merely in terms of the possible redaction activity and its position in the Psalter (Vos 2009:9), and not necessarily restricted to a possible liturgical or cultic context. ${ }^{11}$ Most exegetes regard this Psalm as post-exilic (Anderson 1972:955), and with reference to the importance of music for the post-exilic or second temple Yehud community, Human (2011:9) suggested 350 BCE - 250 BCE as a possible date for Psalm 150.

Of significance is the suggestion that this exilic or post-exilic context can also be described as a context where the cultic activities $^{12}$ contributed towards the identity formation and theological construction within a particular setting of deprivation and loss on the one hand, and reconstruction on the other (Schmid 2012):

The dominance of cult religion generally continues for the entire Second Temple period (515 b.c.e. -70 c.e.), which is rightly regarded as the essential period of formation for the biblical books. (p. 293)

Whilst acknowledging the continuity between the pre-exilic and post-exilic national identity, one also needs to recognise the changes and realignments that characterise the post-exilic community (Brettler 1999:443). This realignment can also be regarded, to a certain extent, as a 'shift from a national identity to that of a religious community' (Coggins 1989:233) where various strategies of intensification ${ }^{13}$ contributed towards the formation and preservation of the post-exilic Yehud community. Amidst the various strategies to facilitate social solidarity (Pirog 2006:44-45), music forms an integral part of the 'affective modes of intensification' (Wise 2004:33):

\footnotetext{
9. A basic question would be whether this call is to praise God with accompaniment by musical instruments, or whether the 'praise of God' - and communicating with by musical instruments, or whether the 'praise of
God - is best expressed or articulated via music?
}

10.See Monger (2012) regarding the musical value of the accents or cantillation marks. See also Berkovits (1994) regarding durational effects in final lengthening.

11.The progressive parallelism in Psalm 150:1 attests to this cosmic awareness, emphasized through the rhythmic sound of drumming forth the presence of the Lord.

12.Concerning the composition and theological perspectives, Human (2011) acknowledges that, at a redactional level, Book V (Pss 107-150) is liturgically orientated.

13.Intensification refers to various utterances and interactions amidst a displaced community to increase affective engagement and maintain the notion of community to increase affective engagement and maintain the notion of
collectivity and a 'space for social belonging', which is central to the 'formation of their collective identities' for traumatised communities (Wise 2004:30)
'Performance, singing, and ritual in particular, tap into and ignite a sense of collective somatic belonging amongst participants'.

It comes as no surprise that this 'song of praise' (Psalm 150) is regarded as the 'concluding doxology of the entire Psalter' (Anderson 1972:955) or the 'grand finale of the crescendo ${ }^{14}$ in the Psalter' (Human 2011:1, own emphasis).

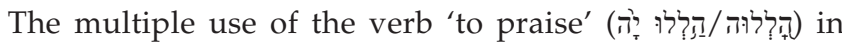
Psalm 150 is a distinctive characteristic of the linguistic and poetic quality of this psalm, whilst the reference to musical instruments alerts one to the fact that music constitutes an integral aspect of the message and significance of the text (Amzallag 2014:26). Furthermore, specific musical expressions constituted an essential component of the perception and transmission of this call to 'praise the Lord'. Not only is it the awareness of this fact that enables the reader to appreciate and participate by listening to the message in a unique manner, the theological significance of the text (text accompanied by musical instruments or just musical expression on its own) is also acknowledged and needs to be defined not only in linguistic terminology. Our conceptualisation and appreciation of the theological significance needs to transcend the linguistic conceptual framework to pave the way for an experiential participatory event. The reference to musical instruments is more than a literary device (Kalimi 2010:569). A basic question would be whether we are dealing here with a song or hymn accompanied by text, that is, 'texted music', or is the reference to musical instruments to be seen as a call to use 'absolute music' without an external textual counterpart (Duffy 2007:1).

Whilst most exegetes define the genre of this Psalm as belonging to a hymn or praise song (Anderson 1972:955; Boadt 1984:282; Human 2011:3; Weiser 1962:841), within the collection of the final Hallel (Psalm 146-150), not much attention is paid to the significant role that music and musical instruments play, except for some description of musical instruments as such and the possibility of their part within the festival liturgy of the temple worship (Weiser 1962:841). In this regard, Weiser (1962:841) emphasised that this praise to God was to be accompanied by 'the triumphant strains of the entire orchestra of the Temple-music'. Briggs and Briggs (1976:544) illustrate the point by stating, with reference to Psalm 150:3-6, that 'the timbrel and other musical instruments of this Str. - strings and pipe, sounding cymbals, and clashing cymbals - are those that accompany the dance', thus being the only comments or explanation regarding the significance of music and musical instruments in appreciating this song of praise. Anderson (1972:587) acknowledges the fact that the usage of the timbrel $(t \bar{o} p)$ (drum or frame drum) was 'often used in dancing' (with reference to Psalm 82:2). Apart from this rather repetitious explanation, not much attention is being given to the theological significance of music and the function of the drum in Psalm 150, albeit tentatively and exploratory in nature.

14.Crescendo - musical term referring to the gradual increase in volume or intensity of a passage of music. 
Music needs to be regarded as a 'constitutive dimension of the poetical composition' of the Psalms (Amzallag 2014:26), specifically in Psalm 150 with its comprehensive inventory of musical instruments. Music must also be regarded as an important mode of religious expression, enabling the participants to embody sacred or religious experience (BoyceTillman 2014:27). In view of the aforementioned, three aspects serve to illustrate how the comparative approach can be augmented by drawing attention to aspects of particular interest for an African reading of the Old Testament: 'music as space to encounter the divine', the infectious nature of music, and 'drumming' as a point of contact between the Old Testament and Africa.

\section{One finger cannot play the drum alone ...}

In our encounter with this specific Psalm, whereby an attempt is being made to enhance the comparative method as a reading strategy and whilst acknowledging the African context (Adedeji 2003:20), ${ }^{15}$ various aspects pertaining to a particular interpretation of Psalm 150 are presented. It is worthwhile to consider this well known expression whereby two basic aspects are being indicated that need to be considered in as far as it informs the argument or presentation.

Firstly, theological formulations and religious activities and expressions are not merely to be seen as an individual or private affair. The nature of this, let's call it a conversation, is deeply rooted in a spiritual environment that calls forth our participation in a unique manner and requires a particular response (Kloppers 2005:192) in our participation and also in our encounters with the text. In our observation and interpretation, we cannot afford to let our description of the perceived reality (text) determine our appreciation of the text and reduce its significance by describing it in historical descriptive terms only.

Care must be taken not to define and thereby reduce the encounter of the 'Other' to linguistic terminology, that is, historicising and textualisation of the concept 'God'. ${ }^{16}$ Furthermore, the reference to musical terms should acknowledge, by implication, the various functions of music, 'such as reinforcing religious identities, establishing a sense of collectivity within religious groups, acting as a means of theological expression ...' (Lynch 2006:482), more specifically so within a context where 'cultic religion' and participation in ritual dominates religious expression (Ro 2011):

In cultic sacrificial systems, an individual in a family, a community, and a people was always regarded as a part of one living entity, not as a self-sustainable independent personality. (p. 413)

15.Adedeji (2003:200) defines contextual exegesis as 'an hermeneutical procedure or method which interprets the Scriptures (hymnic passages inclusive) by taking into account the people's culture and social situations'.

16.The theological significance of the message (music) from the past and the manner in which we express this experience involves much more than simply describing it in terms of an object (text or literature in a narrow sense of the word) from the past independent from our own perception thereof.
Also, with reference to the link between music and religion, Gill (2010:414) alerts us to the fact that 'publicly performed sacred music could even be regarded as being itself a form of public theology'.

The second significant aspect, often ignored in favour of a very specific textual or linguistic understanding of exegesis or analysis, relates to comprehending the encounter between text and reader, past and present, in terms of historical, descriptive terms only, leading to a reduced understanding or conceptualisation of the emotional and spiritual significance thereof. ${ }^{17}$ Very often in literary analysis, the significance of music as accompanying the text is ignored in favour of a semantic or syntagmatic analysis of the text only (Amzallag 2014:18; Lebaka 2014:1). In this regard, the reference to music and musical instruments needs to be re-evaluated and appreciated in as far as music provides a special platform and a sacred space for humankind to encounter God (Boyce-Tillman 2014:27; Sequeri 2013:418). Various records, past and present, indicate that music is an important cultural resource and fulfils a very particular role for religious communities (Gathogo 2008:282-283; Lynch 2006:482; Parrinder 1956:37).

The importance of music as constitutive for understanding worship in the Old Testament cannot be denied (Keown 2012:7), and the reference to various musical instruments invites the reader to explore the connection between music and words in thanksgiving or praise (Hawkins 2001:12).

Simultaneously reading the text with 'an African mind-set' (Van Zyl 1995:429) and acknowledging the theological or spiritual ${ }^{18}$ nature thereof facilitates an authentic reinterpretation and appropriation of the Old Testament text and enables one to 'recapture something of the essence of the faith experience of Old Testament believers' (Van Zyl 1995:436, own emphasis).

It is ironic ${ }^{19}$ and noteworthy that Calvin, as early as 1538 , acknowledged the importance and significance of texts being accompanied by music (melodies) for Christian worship (Stipp 2007:68-72) and realised the expressive potential of the Psalms in this regard (Trocmé-Latter 2009):

Calvin wished to have a set of texts and melodies that could be called upon during divine worship. He strongly believed that the psalms were perfect examples of the way people should communicate with God. He saw in them a potential for engaging people and unifying humanity, and he recognized their ability to act as a 'vehicle' for Christian worship. (p. 336)

17.Met verwysing na ervaring as hermeneutiese sleutel wys De Villiers (2003:283) daarop dat 'Taal word op hierdie manier nie net kognitief-proporsioneel gesien nie, maar die ervarings- en ekspressiewe rol daarvan word ernstig opgeneem'. Rough translation - Language is not seen to be perceived or described in cognitive proportional terms only and the expressive and experiential role thereof is acknowledged.

18.From an African perspective, 'the world and everything in it and life in every aspect are religious' (Van Zyl 1995:430).

19.It is also ironic, given the close relationship between religion and music, and the acknowledgement regarding the various interlocking trends, such as 'the decline of traditional religious institutions, and the rise of alternative spiritualities', that not traditional religious institutions, and the rise of alternative spiritualities , that not
more attention be given to the significance of music in the theological discourse and interpretation of the Bible (Lynch 2006:482). 
Furthermore, Calvin also realised that music had the power to move the human heart (Trocmé-Latter 2009:336). A basic problem is, of course, the enigmatic nature of musical expression. 'Unlike other modes of expression, it tends to shy away from translation in a linguistic sense' (Duffy 2007:1). Although the general assumption is that music serves the text in a complimentary manner, its function is not to be restricted to 'word-painting' (Duffy 2007):

However, music's communicative potential is much broader than mere word-painting: music can enter into dialogue with text, challenging the very words that it sets, criticizing, coloring, and molding them into a new idea. (p. 1)

With reference to the interpretation and influence of the Psalms in the life of the Church and Christian worship, the impact of the psalms came to be defined in terms of music or the fact that 'they have most often been sung' as signifying one 'facet of their power' (Wenham 2009:120). The significance of music is well established and acknowledged by the various references to music and musical terms throughout the Old Testament (Kolyada n.d.:3). ${ }^{20}$ An integral part of the problem regarding the theological significance of music and the distance between the text and the contemporary reader is that 'words about music are secondary to music itself' (Tenny et al. 1975:311). ${ }^{21}$ This restriction should not prevent theology from concerning itself more seriously with music (Sequeri 2013:417). Whilst recognising the importance of music and musical instruments for appreciating particular texts, one also needs to acknowledge the limitations and constraints of this exercise regarding the interpretation and appreciation of the text in what we can refer to as a more comprehensive reading strategy. In so doing, various aspects pertaining to the connotation of music within the text can unlock the significance of Psalm 150 for the contemporary reader and enable us to listen anew to the message carried forth by the rhythm of the drum. The 'speaking drums' (Becken 1995:230) caution us to listen more carefully to the voices from the past.

\section{In his sanctuary ... 'music as space to encounter the divine'! (Psalm 150:1)}

The combination of various musical instruments and the role of these instruments amidst various cultic contexts of Iron Age Palestine is noticeable in the archaeological record as well as the Hebrew Bible texts (Burgh 2004:128ff.). In the Old Testament, music played an important role in worship. This is also evident in the psalms, where music and song are seen as a form of prayer that involves the whole person (Wenham 2009:121). The musical components probably form part of the performance or presentation of the psalm, that is, the laudatory character of this song of praise enhanced the literary form and visual appearance thereof (Vos 2009:11).

Contrary to Leeuenberger (2004:358-364) and Loader (1991:165), it is not just that the 'page layout or visual

20.As indicated by Lebaka (2014:1) 'Studies of music and song in the Old Testament have tended to draw almost exclusively from textual references in the Bible itself'.

21.Monger (2012:13) acknowledges this constraint, indicating that 'original musical values are not known and impossible to reconstruct on the basis of the information available today'. appearance of the printed poem emphasizes the laudatory character of this song' (Vos 2009:11), but rather the manner or musical form that the psalm took complemented the text of this song. In addition to the 'spacial term "sanctuary" and the cosmological depiction "firmament"' as merisms used to express the totality of God's presence (Human 2011:5), music provided a special platform for an encounter with the Lord that transcended participation in specific rituals or festivities in the temple. ${ }^{22}$ Bearing in mind a most likely post-exilic context for this Psalm, the gradual sublimation of the temple cult provided for alternative religious activities, such as music, whereby the presence of God can be experienced in various ways (Schmid 2012):

God becomes present when invoked. This linguistic gesture of invocation becomes the 'place' where an experience of God is possible, a trajectory that will continue later in the construction of the Psalter into a literary sanctuary. (p. 303)

In Psalm 150, the invocation is through the rhythmic sound of the percussion instrument, creating a unique moment, a space to encounter the divine presence.

\section{Praise him ... with the drum ... (Psalm 150:4) ${ }^{23}$}

The link between ritual and music is well known, and as indicated by Scott (1998):

Played, chanted or sung, music adds intensity, heightens the energy of the ritual directed outward, or the perceptions received. For a gentle ritual, music should be smooth and soft; for a powerful ritual, loud with strong rhythms. (Pirog 2006:44) ${ }^{24}$

Furthermore, the infectious nature of music is partly because of the 'decisive space' (Sequeri 2013:418) being created through music (Scher 2009):

Sound gives a fleeting presence to air, making the invisible tangible. Along with smoke, music allows the most elusive aspect of the physical world to be perceived. The invisible and omnipresent qualities of air made it a perfect conduit for those wishing to communicate with the world of the spirits, which was likewise felt to be difficult to glimpse. (p. 24)

The impact or effect of music is multifaceted, and one can distinguish various emotional, mental, and physical impacts, amongst others, strengthening the social, spiritual, cultural and educational experience of those participating in particular rituals (Pirog 2006:44). It speaks for itself that the aesthetic and affective qualities of music cannot simply be reproduced (Monger 2012:13), given the distance between the text and the contemporary reader. ${ }^{25}$ Furthermore, 'both

22.Wenham (2009:122). "I have already observed that the Psalms differ from other parts of the Bible in that they are meant Noteworthy is the comment by to be recited or sung as prayers'.

23.The significance of the frame drum is well depicted in the archaeological record of Iron Age Palestine (Burgh 2004:129).

24.In this regard Taylor (2011) indicated how the difference between 'plosives' and 'nasals' might enhance a particular expression in a phoenetic approach

25.And with reference to a particular presentation, 'This variable intensity is generated by beating the membrane of the drum either with the finger, the palm, the fist, a stick or a beetle, and in combination of times, this "melody" could express very differentiated meanings' (Becken 1995:230). 
religion and music depend heavily upon untranslatable symbols' (Gill 2010:412). However, that should not prevent the contemporary reader from appreciating the significance of music, also in terms of describing the aesthetic and affective impact thereof (Lynch 2006:486), acknowledging the association of varied moods therewith (Lebaka 2014:2). The comments of Viljoen (2006) regarding the influence of music are noteworthy:

Musiek besit die krag om mense te beïnvloed. Die karakter van musiek en die effek wat dit bewerkstellig berus op verskillende elemente van klank en die verhouding tussen hierdie elemente. In sy eenvoudigste vorm kan musiek assosiasies, sensasies, stemmings en emosies oproep. Musiek kan die gevoel van die oomblik reflekteer of dit verander, maar kan ook spesifieke gevoel skep of versterk. [Music has the power to influence people. The character thereof and the influence of music depend on various combinations of sound and its relation to one another. In its simplest form, music brings forth associations, sensations, moods and emotions. Music can reflect or change the feeling of the moment, but can also create or strengthen a particular feeling.] (bl. 762, [author's own translation])

The reference to various musical instruments suggests a polyphonic presentation or performance, and one can, with peace of mind, accept a presentation of this Psalm accompanied by various musical instruments to enhance the perception of the Psalm as well as pro-actively engage the 'reader' or participants in worshipping the Lord (Harrán 2010):

By viewing ancient Hebrew music as polyphonic, Portaleone implied the continuity of its practices from David's time (c. 1000 BCE) until his own. This is clear from his remark that in the Ancient Temple, songs performed vocally (shirat [...] be-fe) and played on instruments (bi-neginat ha-kelim) [...] [ are of] relevance to the practice of that music (zimrah) that singers (meshorerim) today know to perfection'. (p. 220)

Whilst Human (2011:9) acknowledges the significance of music and musical instruments, the significance of the tambourine or frame drum needs further clarification. The drum, described in terms of its construction and function as a membranophone (Kolyada n.d.:4), belongs to the class of percussion instruments. The point is, with the drum comes rhythm, and rhythm can be seen as the 'chief energizer' and 'chief organizer' (Spencer 1988:72). The comments by Spencer (1988:67) regarding the drum are significant, that is, 'to the African, the drum was a sacred instrument possessing supernatural power which enabled it to summon the gods into communion with people'. Furthermore, as indicated by Spencer (1988):

Although the drum was acoustically the ideal instrument to accompany African dance, rhythm was fundamentally the 'chief energizer' and 'chief organizer' which respectively inspired and controlled the activity of a community, causing it to act together and therefore nurture a social nucleus. Rhythm could confidently perform the orchestral part traditionally played by the drum in the climax of religious ritual, for when its percussive voice spoke, the people and their gods listened and were mobilized to converge in the medium of dance. (p. 72)
Noteworthy is the rhythmic repetition ${ }^{26}$ to praise the Lord (praise or בַ verb, piel imperative masculine plural). Apart from the 10-fold repetition to 'praise God' or 'praise Him' used for special emphasis (Anderson 1972:955), the reference to the tambourine or frame drum (Psalm 150:4 - וּמָחזוֹל רְת (1) 'praise Him with tambourine and dance' calls for some special attention.

The tambourine is singled out for its association with dancing (Ex 15:20; Jdg 11:34; 1 Sm 18:6), often played by women (Anderson 1972:587; Human 2011:7).

The manner in which drumming might have accompanied the presentation of the song is audibly not accessible for the contemporary reader. The possible significance of it can be mooted, bearing in mind that various modes of drumming do not transmit words or sentences; rather, they resound the mood of the people in a specific occasion (Becken 1995:230). Music as a method of contacting the spirit world was not restricted or confined to Ancient Israel, as its shamanic significance is widely accepted (Scher 2009):

Along with smoke, music allows the most elusive aspect of the physical world to be perceived ...

Along with rattles, drums were a major part of trance-related music. It has been demonstrated that persistent rhythmic drumming can alter human brainwave patterns, helping to induce a trance state. (pp. 22, 24)

The point is clear - there is a distinctive connection between various religious activities and music which represents one, often unexplored, ${ }^{27}$ dimension of the faith experience of religious communities (Gill 2010:411; Parret 2005:41). As pointed out regarding the function of music and sound, it is important to note that:

sounds of musical instruments and/or human voices being raised emotionally (either in joy or in sorrow, mourning, or fear) and their being heard somewhere else [can function] as a literary device of transitioning the reader from one place or group to another. (Kalimi 2010:565)

It is not possible to fully comprehend the impact of music on a particular receptor or participating audience, and the suggestion by Gill (2010:424) should inform the contemporary reader that 'both music and religious faith require active engagement to be appreciated properly'. The fine line between music as 'personal expression' and music as 'communication' will remain enigmatic and elusive. Exploring the connection and powerful impact of music (De Klerk \& Smit 2002:114) will invite us to discover more about ourselves and God (Petty 2010:74), ${ }^{28}$ bearing in mind the effect of drumming on subjective experiences and the

26.As indicated by Anderson (1972:955) 'the tenfold repetition of the imperative cali "Praise him" or "Praise God" (once in verse 1) may sound rather monotonous, but it is, no doubt, used for the sake of special emphasis'.

27.Viljoen (2006:761) erken die feit dat 'die waarde van musiek in die teologie en godsdiens wêreldwyd grootliks verwaarloos word' [the value of music in/for theology and religions are grossly neglected world-wide] [author's own translation].

28.With reference to an appropriate way of reading the Psalms, Long (2014:23, own emphasis) indicated '... we ought to pray them and sing them rather than preach them', and in addition to the proposed reading strategy, a fifth aspect might be listed-listen to the drum. 
indication that 'drumming can induce an altered state of consciousness' or 'trancelike state of consciousness' (Szabó 2005:58, 51).

\section{Music and 'drumming' as a point of contact between the Old Testament and Africa}

The similarities and compatibility between the world of the Old Testament and that of Africa is widely recognised. A specific aspect thereof pertains to music. Music also translates:

into the mentality of the Africans in word and deed; in this process, they took in the fundamental ideas of hereditary religious conceptions, and this includes, of course, the drum. (Becken 1995:235)

As emphasised by Becken (1995:228) 'surely, the drum is the most marked cult symbol of Africa'. Drumming constituted a space for the encounter with the divine 'other'. From an African perspective, one needs to acknowledge the significance of the drum and its function in various religious / cultic contexts (Gathogo 2008:283). Also, as a musical instrument the drum or 'drumming' enables the individual and the community to participate and express their experience and understanding of the presence of God in an audible manner. ${ }^{29}$

The manner in which music can affect a particular spiritual influence (past and present) should not be underestimated (Weman 1960:198). Music is recognised as a powerful medium of communication (Lebaka 2014:6; Lury 1956:35), and as such, the drum enables one to speak, or even listen, to God. In so doing, this encounter, inclusive of the musical character thereof, redefines the sanctuary - in other words, the presence of God is not only to be defined or experienced in terms of the religious festivities and rituals performed in the Jerusalem temple (contra Anderson 1972:955), but wherever the believer can articulate, also through music (drum), appreciation for the presence of God. In this regard, Gill (2010:410) acknowledged the fact that 'music and religion seem always to have been intertwined'. Bearing in mind its capacity to resacralize (Gill 2010:412), 'music also helps many of us to meditate and be still in the presence of God without the intrusion of words'.

As indicated (Oosthuizen 2006:59) 'the similarities and compatibility of the Old Testament with that African traditional religion has often been the subject of research' (Oosthuizen 1998:16), that is, ritual (Burden 1983); time (Oosthuizen 1993). There are also, at least at face value, similarities in their respective understanding of sin, creation, family, community, that is, a common outlook on life and human existence (Burden 1983:49). In terms of music, the significance of the drum in the Old Testament and in Africa adds another dimension to this similarity or compatibility.

29. In this regard, Wepener refers to the significance of symbols and rituals in various liturgical contexts and, more specifically, non-traditional liturgical spaces ('nietradisionele liturgiese ruimtes') (Wepener 2011:257).
Various possibilities are presented regarding the theological significance of music and musical instruments, for example its part or role in temple worship, different instruments used by different groups of participating congregants, or even with reference to spatiality and the temple structure with the implication of a wider expansion and impact of cultic musical instruments outside the cult (Human 2011:6). ${ }^{30}$ Recognising the significance of the drum can, in the words of West (2005:58), 'strengthen and awaken the recognition of a significant affinity between the religio-cultural/sociopolitical world of and behind the biblical text and African contexts'. The significance of music in both contexts serves as a point of contact between the two worlds, bearing in mind that 'antiphony is the fundamental mode of ritual singing identified by ethnomusicology' (Amzallag 2014:28). And antiphony as a specific form of engagement in religious performance is no stranger to Africa, as indicated by Weman (1960:158) 'The African song technique with a soloist who is answered by a choir, or two choirs singing antiphonally, could be actualized in this way'. Furthermore, 'It is in fact the rhythm of the drums which "crosses" the rhythm of the song, and helps to create the interplay of rhythms which is the foremost distinguishing mark of African music' (Weman 1960:199). The creative an enigmatic impact of drumming is to be explored, even more so in the context of various forms and contexts of religious expression and worship.

In Ancient Israel also, 'antiphony was approached as the essential mode of praising YHWH' (Amzallag 2014:28). More specifically, for Ancient Israel, as in Africa, the rhythmic sound of the drum constituted a particular dimension of this encounter with God, as is evident from the infectious, rhythmic performance evident in Psalm 150.

\section{Conclusion}

The transmission and interpretation of the text (Psalm 150) entails more than the occasional recognition of its function within a liturgical context. It is a well known fact that music 'has, in the past, been an important cultural resource and practice for religious communities' (Lynch 2006:482). Whilst acknowledging the fact that the Psalms consist of larger and smaller collections of Psalms and that the various Psalms needs to be interpreted within a specifically literary and theologically defined context, care must be taken not to define the significance of the individual Psalms merely in historically descriptive and linguistic categories only. Precisely because the 'Psalm has no historical Sitz im Leben or definite cultic situation' and 'Sein Sitz im Leben ist die literature' (Human 2011:3; Seidel 1981:91), the impact and significance of the Psalm(s) can be appreciated and enhanced with reference to the 'infectious' ${ }^{31}$ nature of music and musical

30.The suspicion cast on and the distinction between so-called "profane and noncultic instruments in the list' (Human 2011:6) illustrates the problem of not fully appreciating the significance of music or musical instruments, apart from a linguistic definition thereof and the acknowledgement that these instruments played a role in various contexts, inside and outside the cult.

31.With reference to The performance of the Britten Spring Symphony and the piece associated/based on a Psalm 150, Lynn René Bayley indicated 'Yet again, Hickox is having a ball conducting it and the enjoyment is infectious (listen particularly to the syncopated passages near the end)'. Fanfare January/February 2014, 308. 
instruments, such as the drum. Furthermore, the characteristic composition and 'movement from particular to universal descriptions' evident in the Hallel (Psalm 146-150), as well as the fact that the 'universal cosmic depictions in Psalm 150 indicates this psalm's universal openness and openendedness' (Human 2011:3) provides a stage ('spaces', Human (2011:9) where the reader or interpreter of the psalm can respond to the Psalm from his or her own Sitz im Leben or life context. This response is not to be restricted to a historical descriptive presentation of past readers (so-called 'first reader' $)^{32}$ only.

Furthermore, our interpretation needs to move beyond the 'narrowly conceived mode of exegesis which is represented by most modern critical commentaries' (Childs 1979:523). Music (drumming) enables one to comprehend and articulate a very particular aspect of religious experience, and it is of the utmost importance that this be acknowledged and taken into consideration in the interpretation and appreciation of religious texts, such as Psalm 150. Although we study the psalm today, we must acknowledge the distance between text and context (Human 1997:573). Deist and Burden (1980:114) expound on this distance by referring to the various filters that have an impact on the transmission and reception of the text in various contexts that characterise biblical (textual) interpretation. We must acknowledge how the interpretation by past and present readers of the musical elements may have led to the development of alternative spiritual identities (Lynch 2006:482). After all, 'music and musical instruments not only supply ways of praising God. It is a power that exceeds the praise offered by the singing or speaking or shouting or dancing' (Human 1997:578). And bearing in mind the enigmatic nature thereof, music, as part of religious rituals, adds to the encounter with the 'divine other' ${ }^{33}$ Music, indeed, offers 'praise beyond words' (Human 1997:578).

More specifically, acknowledging the role that the drum plays in African religion and allowing that to inform the contemporary reader provides an instrument to explore and transform some non-semantic features regarding the text (Stern 2013:198) into elements of the text's meaning for the African reader (Weman 1960):

The drum is inseparably united with African song. One has a feeling that the song cannot develop fully if it is not accompanied by one drum, or preferably two drums. It is in fact the rhythm of the drums which 'crosses' the rhythm of the song, and helps to create the interplay of rhythms ... (p. 199)

As such, recognising the significance of the drum within an African context opens up the space for a reading strategy that draws attention to other dimensions pertaining to the interpretation of Psalm 150. Amongst others, the acknowledgement that music (drumming) can be regarded as

32.The psalter entered Christian worship only towards the end of the second century and then only in individual psalms' (Vos 2009:1).

33.And with reference to music and religious rituals Pirog indicated 'Rituals strengthen the social, spiritual, cultural, and educational experiences that churches offer (Pirog 2006:44). a 'constitutive dimension of the poetical composition' (Amzallag 2014:26) allows for an enhancement of the comparative method as reading strategy, whereby the encounter with the 'divine other' is not to be defined in linguistic terminology only and music is to be seen as a specific space to encounter the divine. Furthermore, the comparison between the Old Testament and Africa can, in the realm of music, allow one to 'make contact with the African in one of his most critical activities' (Weman 1960:192) in as far as the 'drum is inseparably united with African song' (Weman 1960:199). Noteworthy is the comment by Gathogo (2008:283) whereby 'ancient Africa relied on drums to announce or call upon the people to assemble'. The drum certainly sheds some light on some aspects pertaining to our encounter with the Old Testament text from an African perspective. Music (drumming) provides a platform that clarifies certain aspects pertaining to the similarities and compatibility between the world of the Old Testament and that of Africa, also regarding various forms of religious experience and expressions thereof. More specifically, the drum ('drumming') can be seen as a point of contact between the Old Testament and Africa, that is, it can be regarded as a unique interplay of rhythms (Weman 1960:199) that enable one to appreciate the interplay of worlds, that is, that of the Old Testament and contemporary Africa ...

And this 'interplay of rhythms' is not to be restricted to music as such, but must most certainly have an impact on our interpretation and understanding of the Biblical text in an African context, where 'theology is danced out' (Van Zyl 1995:56). Maybe, by listening to the talking drums, we can also participate in this spiritual encounter and in so doing identify with and define a particular facet of biblical theology from an African perspective.

\section{Acknowledgements Competing interests}

The author declares that he has no financial or personal relationships which may have inappropriately influenced him in writing this article.

\section{References}

Adedeji, F., 2003, 'Contextual exegesis - An interpretative method for Bible Hymnic Texts: A Nigerian perspective', Asia Journal of Theology 17(1), 17-25.

Amzallag, N., 2014, 'The musical mode of writing of the Psalms and its significance', Old Testament Essays 27(1), 17-40.

Anderson, A.A., 1972, The Book of Psalms, vol. 11 Psalms, pp. 73-150, The New Century Bible Commentary, Wm. B. Eerdmans Publishing co. Grand Rapids, Michigan / Marshall, Morgan \& Scott, London.

Bayley, L.R., 2014, 'BRITTEN. Spring Symphony ${ }^{1}$. Welcome Ode ${ }^{2}$. Psalm 1503', Fanfare: The Magazine for Serious Record Collectors (37)3, 307-308.

Becken, H., 1995, 'Sounds of the double-headed drums', Mission Studies 12(2), 228-246. http://dx.doi.org/10.1163/157338395X00204

Berkovits, R., 1994, 'Durational effects in final lengthening, gapping, and contrastive Stress', Language and Speech 37(3), 237-250.

Bigger, S. (ed.), 1989, Creating the Old Testament: The emergence of the Hebrew Bible, Blackwell, Oxford.

Boadt, L., 1984, Reading the Old Testament. An introduction, Paulist, Mahwah, NJ.

Bonhoeffer, D., 2013, 'Music', viewed 03 October 2013, from http://www.goodreads. com/author/quotes/29333.Dietrich_Bonhoeffer

Boyce-Tillman, J., 2014, 'Music and well-being', TD The Journal for Transdisciplinary Research in Southern Africa 10(2), 12-33.

Brettler, M.Z., 1999, 'Judaism in the Hebrew Bible? The transition from Ancient Israelite Religion to Judaism', Catholic Biblical Quarterly 61(3), 429-447. 
Briggs, C.A. \& Briggs, E.G. (eds.), 1976, The international critical commentary a critical and exegetical commentary on the Book of Psalms, T \& T Clark, Edinburgh.

Burden, J., 1983, 'Are Shem and Ham blood brothers? The relevance of the Old Testament to Africa', Old Testament Essays 1, 49-72.

Burgh, T.W., 2004, “"Who's the man?" Sex and gender in Iron Age musical performance', Near Eastern Archaeology 67(3), 128-136. http://dx.doi.org/10.2307/4132375

Carrington, J.F., 1959, Talking drums of Africa, London [No Publisher].

Childs, B.S., 1979, Introduction to the Old Testament as scripture, SCM Press, London.

City College of New York (CCNY Theatre Ed. Dept.), 2016, 'The music of Africa', in The Lion King \& I, A study guide for the 4th grade, The City College of New York viewed 07 June 2016, from http://education.ccny.cuny.edu/website/edtheatre/ LionKingStudyGuideUpdated.pd

Coggins, R.J., 1989, 'After the exile', in S. Bigger (ed.), Creating the Old Testament: The emergence of the Hebrew Bible, pp. 229-249, Blackwell, Oxford.

Deist, F.E. \& Burden, J., 1980, 'n ABC van Bybel uitleg, JL van Schaik, Pretoria.

De Klerk, B.J. \& Smiot, E.J., 2002, 'Pneuma en nous in die gereformeerde kerklied: Perpsektiewe uit 1 Korintiërs 14:5 en die tradisie, toegespits op die musiek en poësie van die kerklied', Die Skriflig 36(1), 105-124. http://dx.doi.org/10.4102/ ids.v36i1.498

De Villiers, P.G.R., 2003, 'Religieuse ervaring as hermeneutiese beginsel in die interpretasie van bybeltekste in die lig van die boek Openbaring (religious light of the book Revelation', NGTT 44(3\&4), 276-287.

Duffy, C., 2007, 'Choral music as literary criticism: A study of the textual dimension of music's meaning', American Choral Review 49(2), 1-5.

Gathogo, J.M., 2008, 'Some expressions of African hospitality today', Scriptura 99, 275-287. http://dx.doi.org/10.7833/99-0-669

Gill, R., 2010, 'Public theology and music', International Journal of Public Theology 4 410-425. http://dx.doi.org/10.1163/156973210X526391

Harrán, D., 2010, 'In search of the "Song of Zion": Abraham Portaleone on music in the ancient temple', European Journal of Jewish Studies 4(2), 215-239. http://dx.doi. org/10.1163/102599911X573341

Hawkins, P., 2001, 'A howl of despair', Christian Century, 06-13 June, 12.

Healy, J. \& Sybertz, D., 1996, Towards an African narrative theology, Orbis Books, Maryknoll, NY.

Hester, K.E., 2010, Bigotry and the Afrocentric 'Jazz' evolution, Cognella, San Diego, CA.

Human, D.J., 1997, 'Interpreting the Bible in the 'new' South Africa: Remarks on some problems and challenges', HTS Teologiese Studies/Theological Studies 3(3) 570-579. http://dx.doi.org/10.4102/hts.v53i3.1667

Human, D.J., 2011, 'Praise beyond words": Psalm 150 as grand finale of the crescendo in the Psalter', HTS Teologiese Studies/Theological Studies 67(1), 1-10. http:// dx.doi.org/10.4102/hts.v67i1.917

Kalimi, I., 2010, 'Human and musical sounds and their hearing elsewhere as a literary device in the Biblical narratives', Vetus Testamentum 60, 565-570. http://dx.doi. org/10.1163/156853310X536761

Keown, M., 2012, 'How much should we sing?', New Zealand Journal of Christian Thought \& Practise 19(3), 4-13.

Kloppers, E., 2005, 'Handelinge in die erediens: Die verryking van die liturgie deur musiek', HTS Teologiese Studies/Theological Studies 61(1\&2), 191-208. http:// dx.doi.org/10.4102/hts.v61i1/2.446

Kolyada, Y., 2009, A compendium of musical instruments and instrumental terminology in the Bible, Equinox publishing, London.

Kolyada, Y., (n.d.), A compendium of musical instruments and instrumental terminology in the Bible, viewed 23 July 2014, from http://site.ebrary.com/ terminology in the
id/10386849?ppg $=1$

Kwami, R., 1989, 'Towards a comprehensive catalogue of Eve drum mnemonics', Journal of African Cultural Studies 11(1), 27-38. http://dx.doi.org/10.1080/13696 819808717824

Lebaka, M.E.K., 2014, 'Music, singing and dancing in relation to the use of the harp and the ram's horn or shofar in the Bible: What do we know about this?', HTS Teologiese Studies/Theological Studies 70(3), Art. \#2664, 7 pages. http://dx.doi. org/10.4102/hts. v70i3.2664

Le Roux, J., 2002, 'Gadamer en die Ou Testament', Ou Testament Nuusbrief, 10 May, p. 15.

Leuenberger, M., 2004, Konzeptionen des Königtum Gottes im Psalter: Untersuchungen zu Komposition und Redaktion der theokratischen Bücher IV-V im Psalter, ATANT 83, Theologischer Verlag, Zürich.

Loader, J.A., 1991, 'God se hemelgewelf', in C.J.A. Vos \& J.C. Müller (eds.), Mens en omgewing, pp. 164-173, Halfway House, Johannesburg, Orion.

Long, T.G., 2014, 'Four ways to preach a Psalm', Journal for Preachers 37(2), 21-32.

Lowell, P., 1995, 'Dancing to the drums of praise: Impact international', Christianity Today 39(6), 58.

Lury, C.E.E., 1956, 'Music in African churches', African Music 1(3), 34-36. http:// dx.doi.org/10.21504/amj.v1i3.312

Lynch, G., 2006, 'The role of popular music in the construction of alternative spiritual identities and ideologies', Journal for the Scientific Study of Religion 45(4), 481-488. http://dx.doi.org/10.1111/j.1468-5906.2006.00322.x

Martey, E., 1993, African theology: Inculturation and liberation, Orbis Books, Maryknoll, NY

Monger, M.P., 2012, Accents, punctuation or cantillation marks? A study of the linguistic basis of the to àmim, Masteroppgave Trykk: Reprosentralen, Universitetet i Oslo, Oslo.
Oerhle, E., 2013, 'The talking drum: Towards the dissemination of music in South Africa', Journal of the Musical Arts 10, 135-138. http://dx.doi.org/10.2989/18121 004.2013.846991

Oosthuizen, R., 1993, 'African experience of time and its compatibility with the Old Testament view of time as suggested in the genealogy of Genesis 5', Old Testament Essays (6/2), 190-204.

Oosthuizen, R., 1998, 'What "African" means for South African Old Testament scholarship', Newsletter on African Old Testament Scholarship 5(November),

Oosthuizen, R.D.W., 2006, 'An African perspective on 2 Sam 18:21 (2 Sam 17:24-19:8a/9a): Was Joab a racist?', The South African Baptist Journal of Theology 15, 55-62.

Oosthuizen, R.D.W., 2016, 'The drum and its significance for the interpretation of the Old Testament from an African perspective: Part one', Verbum et Ecclesia 37(1) a1395. http://dx.doi.org/10.4102/ve.v37i1.1395

Parret, G.A., 2005, '9.5 Theses on a disputation on the role of music', Christianity Today, February, pp. 38-42.

Parrinder, E.G., 1956, 'Music in West African churches', African Music 1(3), 37-38. http://dx.doi.org/10.21504/amj.v1i3.314

Petty, M.C., 2010, 'Hymns, music and spirituality', European Journal of Theology 19(1),

Pirog, E., 2006, 'The power of music', Journal of Religion \& Psychical Research 29(1), $42-47$.

Ro, J.U., 2011, 'The theological concept of YHWH's punitive justice in the Hebrew Bible: Historical development in the context of the Judean community in the
Persian period', Vetus Testamentum 61, 406-425. http://dx.doi.org/10.1163/156 Persian period',
853311X594694

Scher, S., 2009, 'Breath of the Ancestors', Ceramics Technical 28, 21-26.

Schmid, K., 2012, 'The Canon and the cult: The emergence of book religion in Ancient Israel and the Gradual Sublimation of the Temple Cult', Journal of Biblical Literature 131(2), 289-305.

Scott, G., 1998, 'Using rituals to achieve your goals', Psychic Advisor, May.

Seidel, H., 1981, 'Ps. 150 und die Gottesdienstmusik in Altisrael', NederlandsTheologisch Tijdschrift 35, 89-100.

Sequeri, P., 2013, 'Music and resurrection', Toronto Journal of Theology 29(2), 417-421. http://dx.doi.org/10.3138/tjt.29.2.417

Spencer, J.M., 1988, 'Rhythm in black religion of the African Diaspora', Journal of Religious Thought 44(2), 67-82.

Stern, E.R., 2013, 'What is Jewish scripture?', Biblical Theology Bulletin 43(4), 191-199. http://dx.doi.org/10.1177/0146107913504878

Stipp, N., 2007, 'The music philosophies of Martin Luther and John Calvin', American Organist Magazine 41(9), 68-72.

Szabó, C.S., 2005, 'The effect of monotonous drumming on subjective experiences', in D. Aldridge \& J. Fachner (eds.), Music and altered states: Consciousness, transcendence, therapy and addictions, pp. 51-59, Jessica Kingsley Publishers, London.

Taylor, M.L., 2011, 'Poetry and the art of sound: How to manipulate the musicality of language to help convey your meaning', Writer (Kalmbach Publishing Co.) 124(4), 18-19.

Tenny, M.C. (ed.), 1975, The Zondervan pictorial encyclopaedia of the Bible, vol. 4. Music: Musical Instruments, pp. 311-323, Grand Rapids Zondervan Corporation, Michigan.

Trocmé-Latter, D., 2009, “May those who know nothing be content to listen”: Loys Bourgeois's Advertissement to the Psalms (1551)', Reformation \& Renaissance Bourgeois's Advertissement to the Psalms (1551)', Reformation \& R
Review: Journal of the Society for Reformation Studies 11(3), 335-347.

Tull, P., 2000, 'Intertextuality and the Hebrew scriptures', Currents in Research: Biblical Studies 8, 59-90.

Ukpong, J.S., 1999, 'The historical critical approaches/Can African Old Testament Scholarship escape the historical critical approach', Newsletter on African Old Testament Scholarship 7, 2-5.

Van Zyl, D.C., 1995, 'In Africa theology is not thought out but danced out - On the theological significance of Old Testament symbolism and ritual in African Zionist churches', Old Testament Essays 8(3), 425-438.

Viljoen, A.M., 2006, 'Die waarde en funksie van liturgiese musiek', NGTT 47(3\&4), 760-771.

Vos, C.J.A., 2009, 'The Psalms as hymns in a liturgical context', HTS Teologiese Studies/ Theological Studies 65(1), Art. \#105, 6 pages. http://dx.doi.org/10.4102/hts. v65i1.105

Vos, C.J.A. \& Müller, J.C. (eds.), 1991, Mens en omgewing, Orion, Halfway House, Johannesburg.

Weiser, A., 1962, The Psalms, SCM Press, London.

Weman, H., 1960, African music and the church in Africa, transl. E.J. Sharpe, $A B$ Lundequistska Bokhandeln, Uppsala.

Wenham, G.J., 2009, 'Reflections on singing the Ethos of God', European Journal of Theology 18(2), 115-124.

Wepener, C., 2011, 'Nuwe tendense buite-om die erediens van die 21ste eeu. ' $n$ Beskrywende liturgie-historiese en hedendaagse verkenning', NGTT 52(1\&2), 257-271. http://dx.doi.org/10.5952/52-1-24

West, G., 2005, 'Shifting perspectives on the comparative paradigm in (South) African Biblical Scholarship', Religion \& Theology 12(1), 48-72. http://dx.doi.org/10.1163/ 157430105X00121

Wise, A., 2004, 'Embodying exile: Trauma and collective identities among East Timorese Refugees', Australia Social Analysis 48(3), 24-39. http://dx.doi. org/10.3167/015597704782352456 